\title{
CA 125 yüksekliği ile seyreden Meigs' Sendromu: Olgu Sunumu
}

\author{
Meigs' Syndrome with Elevated Serum CA125: Case Report
}

\author{
Esin KASAP ${ }^{1}$ M.D., Mine GENC ${ }^{1}$ M.D., Berrin KORKUT ${ }^{1}$ M.D.., Neslin SAHIN² M.D.,Sibel DEMIR ${ }^{3}$ MD
}

1. Department of Obstetrics and Gynecology, Sifa University School of Medicine, İzmir, Turkey

2. Department of Radiology, Sifa University School of Medicine, İzmir, Turkey

3. Department of Patology, Sifa University School of Medicine, İzmir, Turkey.

\section{ABSTRACT}

An elevated serum CA125 level in association with a pelvic mass, pleural effusion, and massive ascites usually signifies a dismal prognosis in a postmenopausal woman. However, surgery and histopathological examination are required for the correct diagnosis and treatment,since an elevated CA125 level can be falsely positive for ovarian malignancy. We present a case of Meigs' syndrome due to left ovarian fibroma with elevated CA125 level in a postmenopausal woman.

Key Words: Meigs' syndrome · Ascites · Pleural effusion · Serum CA125

\section{ÖZET}

Postmenapozal hastalarda serumda artmış CA 125 birlikteliği ile beraber pelvik kitle,plevral efüzyon, masif asit varlığı genellikle kötü prognozu işaret eder. Bununla beraber doğru tanı ve tedavi için operasyon ve histopatolojik inceleme gereklidir çünkü yüksek CA125 düzeyi ovarian malignensi için yanlış pozitif olabilir. Biz bu yazıda postmenapozal hastada CA 125 yüksekliği ile seyreden sol ovarial fibromanın eşlik ettiği Meigs' Sendromu olgusunu sunuyoruz.

Anahtar Kelimeler: Meigs' Sendromu, Asit,Plevral efüzyon, Serum CA 125 


\section{Giriş̧}

Over fibromları seks kord-stromal hücreli tümörler grubundandır ve overin en sık benign tümörü olup benign over tümörlerinin yaklaşık \%1-4'ünden sorumludurlar(1). Fibromalar genellikle 2-3. dekatta sık görülür,bu tümörler genellikle unilateral olup \%70'i sol overde lokalizedir. En sık semptomlar abdominal rahatsızık hissi ve ağrı olup birçok hastada herhangi bir spesifik semptom vermeyebilir(2). Over fibromalarına nadiren asit ve serumda kanser antijeni 125 (CA 125) yüksekliği eşlik eder ki bu durumda klinik tablo malign bir over tümörüne benzeyebilir. Asit ve hidrotoraks ile karakterize edilen Meigs sendromu riski, özellikle $10 \mathrm{~cm}$ 'den büyük tümörlerde artmaktadır (3).

Biz bu makalede, Meigs sendromu ve karın ağrısı ile illişkilendirilen ve laparotomik cerrahi ile tedavi edilen dev over fibromu olgusunu bildiriyoruz.

\section{OLGU}

62 yaşında bayan hasta;özellikle sol alt kadranda zaman zaman da tüm batına yayılan ağrı, karın şişliği ve nefes darlığı nedeniyle hastanemize müracaat etti. Hastanın 3 normal vajinal doğum hikayesi mevcuttu ve 15 yıldır menopozda olduğu öğrenildi. Geçmişte herhangi bir tıbbi ya da cerrahi hastalığı yoktu.

Fizik muayenede, alt abdomenden başlayıp umblikusun yukarısına kadar uzanıp neredeyse bütün abdomeni işgal eden ve hareketleri kısıtlayan bir kitle tespit edildi. Uterus ve adneksler bimanüel pelvik muayenede değerlendirilemedi. Pelvik ultrasonografi tüm abdomende asit varlığını ve antevert genişlemiş uterusun $(67 \times$ $54 \times 64 \mathrm{~mm}$ ) olduğunu gösterdi. Adneksiyal yapılar ayırt edilemiyordu. Uterus komşuluğunda, hipogastrik bölgeden epigastrik bölgeye uzanım gösteren ve neredeyse tüm abdomeni işgal eden homojen olmayan bir kitle $(250 \times 170 \times 150 \mathrm{~mm})$ tespit edildi. Hastanın Pelvik MR görüntülemesinde; batında yaygın asitin yanısıra solda daha belirgin bilateral plevral sıvı izlendi (Şekil 3A). Pelvisi dolduran $25 \times 17 \times 15 \mathrm{~cm}$ boyutlarında ha- fif lobüle konturlu T2-ağılıklı serilerde (Şekil 3B) sağ yarısı kistik özellikte, sol yarısı intermediate sinyal intensitesinde solid görünümde mikst karakterde kitle lezyonu saptandı. T1-ağırlıklı serilerde (Şekil 3C) lezyonun solid komponenti kaslar ile izointensti. IVKM verilmesini takiben, solid komponentte kontrast tutulumu izlendi.

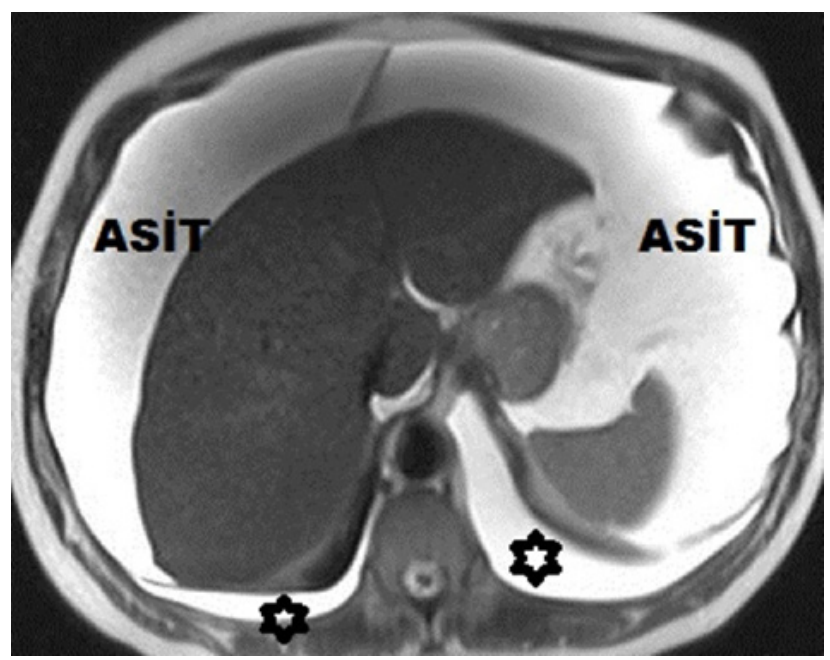

Şekil 3: Abdominal ağrı şikayeti ile gelen 62 yaşında bayan hasta

3(A): T2-ağırlıklı aksiyel kesitte karaciğer ve dalağı çevreleyen yaygın asit yanısıra solda daha belirgin plevral sıvı (yıldız) izleniyor.

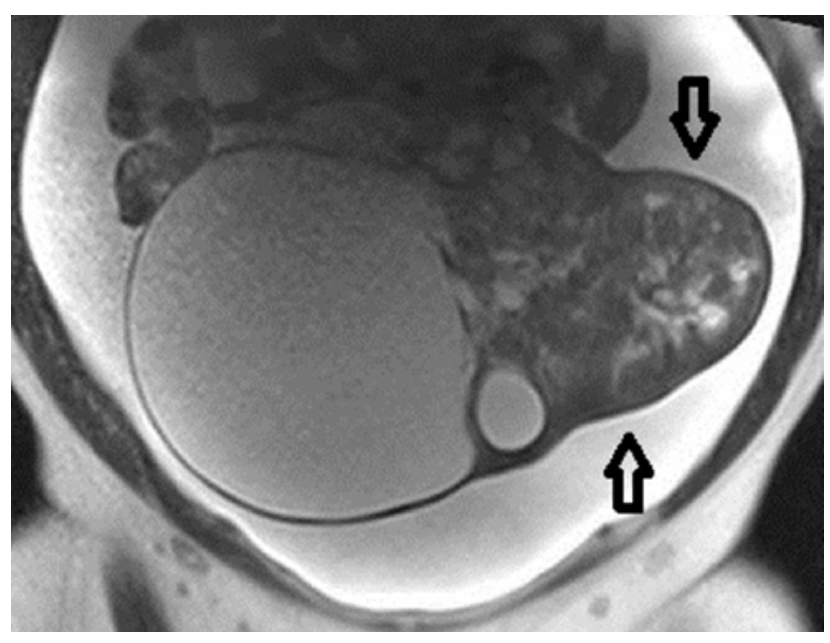

3(B): T2-ağırlıklı koronal kesitte pelvisi dolduran 25x17×15 cm boyutlarında sağ yarısında kistik sol yarısında solid komponentin (oklar) hakim olduğu mikst karakterde kitlesel lezyonu görülüyor.Kitleyi çevreleyen yaygın asit mevcut. 


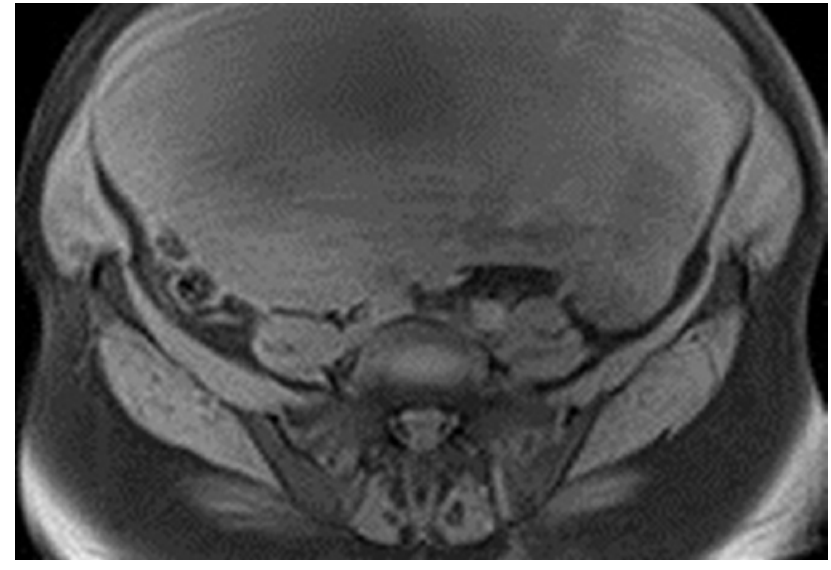

3(C): Yağ-baskılamalı T1-ağırıklı aksiyel kesitte kitle lezyonunun solid komponenti kaslar ile izointenstir.

3(D): IV kontrast madde verilmesini takiben, lezyon solid komponentinde kontrast tutulumu (oklar) izleniyor.

Hastanın Biyokimyasal parametrelerinde herhangi bir özellik saptanmazken; CEA-125 düzeyi $508 \mathrm{IU} / \mathrm{ml}$ olarak tespit edildi. Hastanın onamı alındıktan sonra hastaya laparotomi planlandı. Hastaya yapılan laparotomi sırasında sol adneksiyal alandan köken alan ve umblikusa kadar uzanan $25 \times 20 \mathrm{~cm}$ 'lik yer yer solid ve kistik komponentleri olan kitle tespit edildi (Şekil 1). Ayrıca yaklaşık $2000 \mathrm{~mL}$ ascites mayii batından boşaltıldı. Spesimenin frozen kesitinin intraoperatif histolojik incelemesinde over fibromu tanısı konuldu. Bunun üzerine hastaya total abdominal histerektomi ve bilateral salpingo-ooferektomi uygulandı.

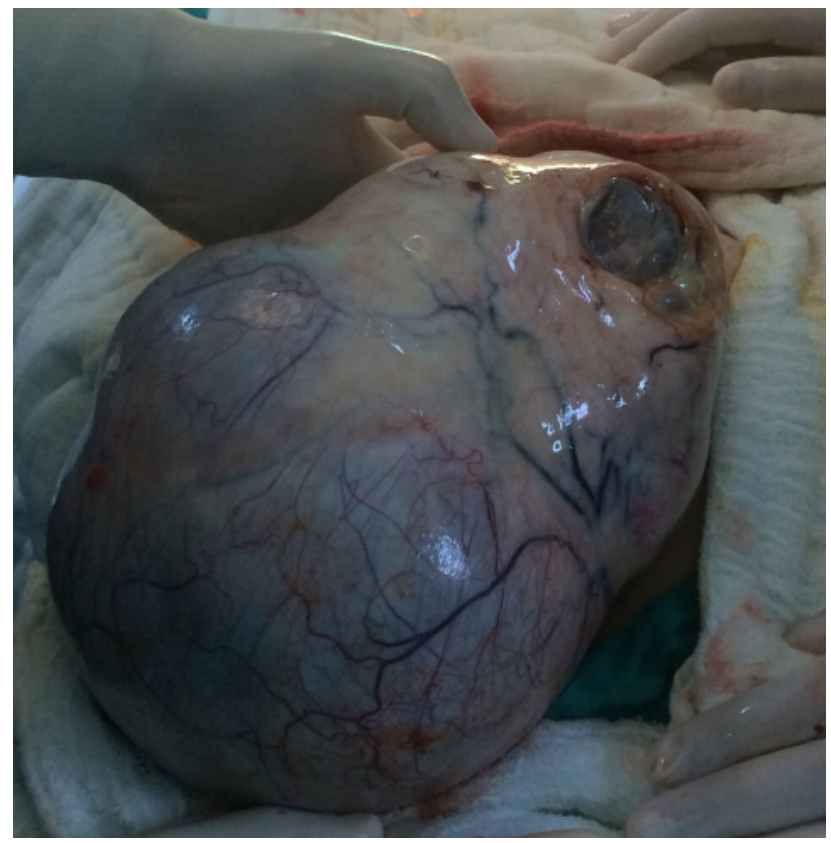

Şekil 1: Sol ovarial fibromaya ait ameliyat specimenin makroskopik Görünümü
Operasyon süresi yaklaşık 60 dakikaydı. Ciddi kan kaybı ya da anestezi komplikasyonu gözlenmedi. Cerrahi spesimenin postoperatif histopatolojik incelemesinde;birbirini kesen iğsi hücre bantlarının yer yer stariform patern oluşturduğu dikkati çekti. Tümörde gevşek ödemli hiposellüler alanlar yanısıra hipersellüler alanlar dikkati çekti. Kollajen üreten iğsi hücrelerin yer yer hyalinize fibröz doku bantları oluşturduğu saptandı. Olguya ovarian fibroma tanısı konuldu. Gönderilen asit sıvısının mikroskobik incelemesi benign özellikte reaktif mezotelial hücreler izlendi (Şekil 2).

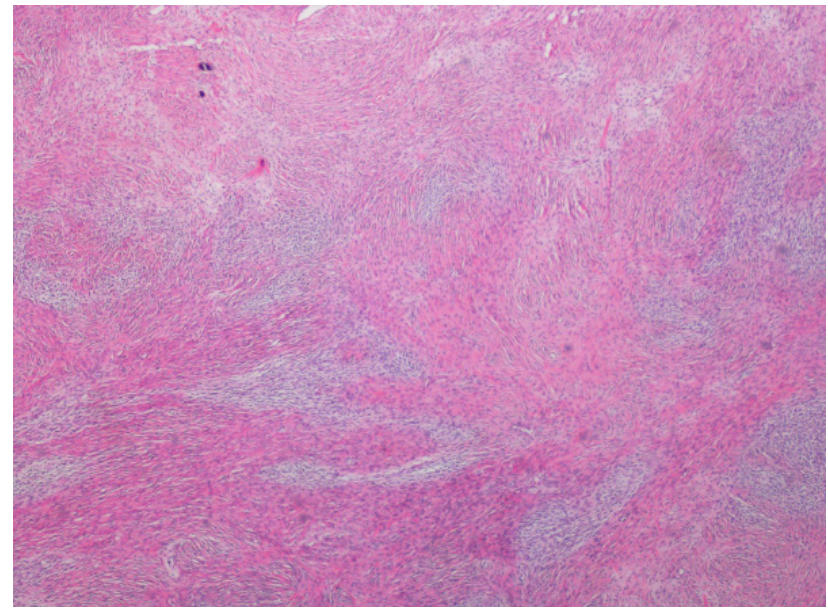

Şekil 2: Sol ovarial fibromanın mikroskopik görünümü (hematoxylin-eosin, $400 x$ ).

Hasta operasyondan 3 gün sonra taburcu edildi. Taburcu edildikten 7 gün sonra normal sosyal aktivitelere döndüğünü bildirdi ve 1 ay sonra tam olarak iyileşip asemptomatik hale geldi.

\section{TARTIŞMA VE SONUÇ}

Bu makale, abdominal ağrı ve Meigs sendromu ile presente olan nadir bir dev over fibromu vakasını sunmaktadır. Over fibromları asit ve plevral efüzyon ile ilişkili olup bu duruma Meigs sendromu denilmektedir (4).

Meigs sendromu; plevral efüzyon, asit ve benign over tümör (sıklıkla fibroma) birlikteliği olmakla beraber, bu birliktelik tekoma, granüloza hücreli tümör ve Brenner tümörü ile de bildirilmiştir. Bu antite, over tümörün rezeksiyonu sonrası plevral efüzyon ve asitin ortadan kalkması ile de karakterizedir. Spielberg 1866 'da sendromun ilk tanımını yapmıştır; bundan 2 dekat sonra Tait, over tümör, asit ve plevral efüzyonun her zaman 
malignite ile ilgili olmadığını bildirmiştir. Demons 1903'te over kitle rezeksiyonu ile semptomların düzeldiğini bildirmiş ve 1937 'de Meigs ve Cass 7 hastada triadı tarif etmişlerdir (5).

Fibromalar tüm over tümörlerin \% 2-5'ini oluştururlar. Fibromaların \% 10-15'i asitle ilişkilendirilmekte ve yalnızca \%1'i eşzamanlı asit ve plevral efüzyon ile prezente olurlar (6). Ana teoriye göre, tümör yüzeyinden transüdasyon mekanizması peritoneal reabsorbsiyon kapasitesini aşar. Bir diğer mekanizma ise tümöral kitlenin kendisinin ya da tümör tarafından salınan vazoaktif maddelerin peritoneal lenfatik damarların ve bölgesel venlerin konjesyonuna yol açmasını klinik prezentasyondan sorumlu tutar(6). CA125'e yönelik immünohistokimyasal çalışmalar Meigs sendromlu hastalarda serum CA125 antijeninde artışın, CA125'in fibromadan ziyade mezotelyal ekspresyonundan kaynaklandığını göstermiştir(7). Kesin mekanizma net olmamak- la birlikte,büyük bir tümörün mekanik iritasyonu, ya da büyük asit hacmine bağlı intraperitoneal basınç artışının bu süreçte ana faktörler olabileceği düşünülmektedir.

CA 125 tümör markeri genellikle malign over tümörlerde artar. Bununla birlikte, endometriyozis, pelvik inflamatuar hastalık ve üterin leiomyoma gibi benign hastalıklarda da artabilir. Serum CA 125 düzeyleri perikardiyal, plevral ve peritoneal iritasyon ya da inflamasyon ile de artabilir(6). Laparotomi ve histopatolojik değerlendirme over tümörlerin doğru tanı ve tedavisi için gereklidir, çünkü artmış serum CA 125 düzeyleri over malignansı için yanlış pozitif olabilir(6).

Palpabl pelvik kitle,asit,plevral efüzyon ve artmış serum CA 125 düzeyleri olan postmenopozal kadınlarda ilk akla gelen overin malign tümörleridir. Bununla birlikte, Meigs sendromunun bir parçası olarak overial fibromalar da akılda tutulmalıdır.

\section{KAYNAKLAR}

1. Chechia A, Attia L, Temime RB, Makhlouf T, Koubaa A: Incidence, clinical analysis, and management of ovarian fibromas and fibrothecomas.Am J Obstet Gynecol.2008, 199:471-474.

2. Sivanesaratnam V.,Dutta R., Jayalakshmi P.Ovarian fibroma Clinical and Histopathological Characteristics. Int.J.Gynecol.Obstet.1990;33:243-247

3. Paladini D.,Testa A.,Van Holsbeke C, Mancarı R, Timmerman $D$,Valentin L. Imaging in gynecologicaldisease (5): clinical and ultrasound characteristics in fibroma and fibrothecoma of the ovary. Ultrasound Obstet Gynecol. 2009;34:188-195
4. Meigs JV, Cass JW: Fibroma of the ovary with ascites and hydrothorax with report of seven cases. Am J Obstet Gynecol 1937, 33:249-266.

5. Lurie S. Meigs' syndrome: the history of the eponym. Eur J Obstet Gynecol Reprod Biol 2000;92:199-204.

6. Abad A, Cazorla E, Ruiz F, Aznar I, Asins E, Llixiona J. Meigs' syndrome with elevated CA125: case report and review of the literature.Eur J Obstet Gynecol Reprod Biol 1999;82:97-9.

7. Timmerman D, Moerman P, Vergote I: Meigs' syndrome with elevated serum CA 125 levels: two case reports and review of the literature. Gynecol Oncol.1995;59:405-408. 